\title{
Геолог Владивостокской крепости Павел Виттенбург
}

\author{
Посвящается паляти Евгении П. Виттенбург
}

\begin{abstract}
Владивостокская крепость - признанный шедевр фортификационного искусства, но мало кто знает, что строительство связано с именем известного российского ученого Павла Владимировича Виттенбурга. Хотя его должность геолога Владивостокской крепости и не была официальной, он оказал большую помощь в сооружении цитадели, обеспечив ее строителей подробнейшими геологическими материалами.
\end{abstract}

Будущий геолог родился 9 февраля 1884 г. во Владивостоке и был восьмым ребенком в семье сосланного в Сибирь участника Польского восстания [1]. В детские годы Павел не отличался усидчивостью и прилежанием, и его исключили из третьего класса гимназии "за нерадение к наукам". Другой мужской гимназии во Владивостоке того времени не существовало, и мальчика отправили к родственникам в г. Либаву (1899). Там в 1905 г. он окончил с отличными оценками реальное училище и уехал учиться в Германию, в Тюбингенский университет, где изучал геологию в качестве основной специальности, а химию и ботанику - дополнительных (фбото 2). Как трудолюбивого студента, подающего большие надежды, Павла премировали стипендией для поездки с научной целью в любой регион вне Европы. Он выбрал Дальний Восток, собираясь исследовать геологию полуострова Муравьева-Амурского ( бото 5). Город, где он родился и где жили родственники, был ему дорог, и он не мог упустить случая побывать там.

Приехав во Владивосток летом 1908 г., П. Виттенбург сразу же направился в музей Общества изучения Амурского края (ОИАК), который знал с детства. Там он нашел поддержку своим планам: член ОИАК К.Н. Бражников, заведующий охраной рыбных промыслов, выделил молодому геологу небольшое судно, на котором он смог совершать плавания вдоль побережья полуострова Муравьева-Амурского и близлежащих островов и собирать требуемый ему для исследований палеонтологический и геологический материал. 16 августа Виттенбург сделал свой первый научный доклад, выступив с предварительным отчетом на общем собрании ОИАК [5, с. 3], а собранный материал послужил темой для докторской диссертации, защищенной в Штутгарте после возвращения с Дальнего Востока [8].

Окончив на следующий год университет с дипломом доктора естественных наук, Виттенбург вернулся в Петербург, где стал работать в Геологическом комитете на должности сверхштатного коллектора, участвуя в экспедициях Геолкома. Дальний Восток продолжал привлекать его. Уже летом

\section{(c) Хисамутдинов А. А., Хисамутдинова Н. В., 2021}

ХИСАМУТДИНОВ, Амир Александрович, д-р ист. наук, заведующий отделом научно-исследовательской работы Центральной научной библиотеки, Дальневосточного отделения РАН, профессор Дальневосточного федерального университета (2. Владивосток). E-mail: khisamut@ yahoo.com

ХИСАМУТДИНОВА, Наталья Владимировна, д-р ист. наук, профессор кафедры межкультурных коммуникаций и переводоведения Владивостокского государственного университета экономики и сервиса (2. Владивосток). E-mail: khisamut@yahoo.com

Авторы благодарят Евгению Павловну Виттенбург (1922-2015) за многолетнюю дружбу и помощь в составлении биографии ее отца.

Представленные в статье фотографии взяты из личного собрания Евгении Павловны Виттенбург (данные материалы были переданы А.А. и Н.В. Хисамутдиновым в 2000 году). 


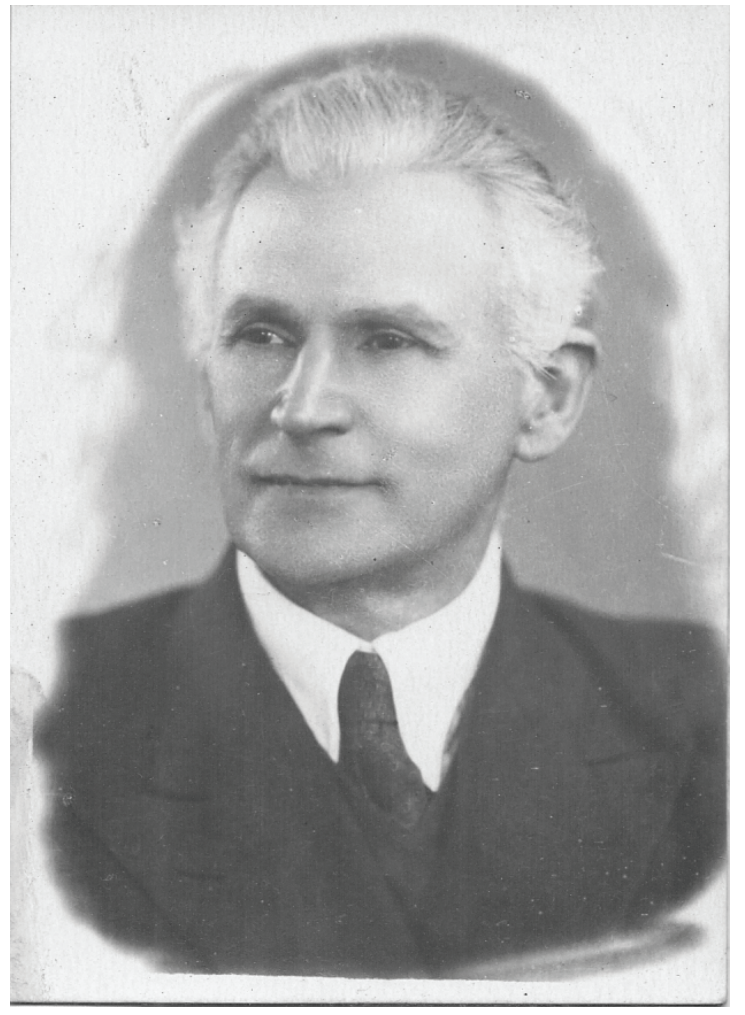

Фото 1. П.В. Виттенбург - профессор Высшего арктического училища имени Макарова. 1949 г.
1909 г. он исследовал Анненские минеральные воды на Амуре и триасовые отложения в Уссурийском крае.

Приоритетными задачами Геологического комитета была разведка полезных ископаемых, a научные интересы молодого ученого были больше связаны с фундаментальными проблемами геологии, и в 1912 г., защитив магистерскую диссертацию по минералогии и геогнозии в Юрьевском университете, он занял должность младшего ученого хранителя Геологического музея Императорской Академии наук (ИАН).

В этот период во Владивостоке и его окрестностях велись большие строительные и фортифоккационные работы военного ведомства. Участие Виттенбурга в этом важном деле связано с именем Николая Матвеевича Соловьева (1861, Москва - 1932, Никольск-Уссурийский), избранного председателем распорядительного комитета ОИАК на том самом собрании 1908 г., когда молодой геолог отчитывался о первых научных работах. Соловьев окончил в 1882 г. инженерное отделение Межевого института в Москве и некоторое время работал сотрудником астрономических и магнитных обсерваторий института.

В 1896 г. его назначили на ответственную должность главного контролера по казарменным и крепостным сооружениям в Южно-Уссурийском крае. Соловьев интересовался краеведением и, приехав во Владивосток, в тот же год вступил в члены ОИАК. В 1912 г. он решил воспользоваться своими связями и провести исследования на полуострове Муравьева-Амурского. Он обратился в инженерное управление Владивостокской крепости с ходатайством о финансировании экспедиции, которая могла бы помочь составить геологическую карту полуострова Муравьев-Амурский. Этим предложением заинтересовались и выделили 2000 рублей с условием, что геологическая карта и дуплетная петрографическая коллекция будут предоставлены в распоряжение Управления строителя крепости. Для проведения этих работ Соловьев и пригласил Виттенбурга.

Геолог отзывался о предстоящей работе следующим образом: "Конечно, с большим колебанием, но с неменьшей готовностью приложить свои скромные знания на пользу изучения родного мне края, я принял лестное для меня предложение Комитета, и настоящие строки являются ответом на поставленные мне вопросы. Едва ли мне нужно упоминать о том, что я не могу признать свой ответ удовлетворительным, ибо каждый ответ порождает целый ряд новых вопросов, для решения которых необходима дальнейшая работа и дальнейшие наблюдения" [2, с. 3].

Виттенбург приехал во Владивосток в начале мая 1912 г. и работал здесь четыре летних месяца, имея в качестве помощников одного студента и, краткое время, консерватора музея ОИАК Николая Петровича Крылова. Обойдя, где пешком, где на лодке, береговую линию всего полуострова Муравьева-Амурского и острова Русского, он собрал огромное количество геологических образцов и материалов: 1400 экспонатов палеонтологической коллекции и 1186 
петрографических экспонатов [6, с. 1-2]. Вкупе с материалами предыдущих экспедиций они позволяли приступить к детальному описанию геологического строения полуострова.

"В 1908 году я уже имел случай бегло обследовать строение западного и восточного берега полуострова Муравьева-Амурского, - писал Виттенбург, - и в следующем 1909 году мне удалось пополнить свои сведения об этой береговой полосе во время непродолжительной экскурсии в центральную часть полуострова Муравьева. Лишь в 1912 году я мог собрать в продолжение 4-месячной работы необходимый геологический материал по инициативе и программе Распорядительного комитета Общества изучения Амурского края во Владивостоке" [2, с. xхvi].

Геолог также отмечал большую помощь, которую он

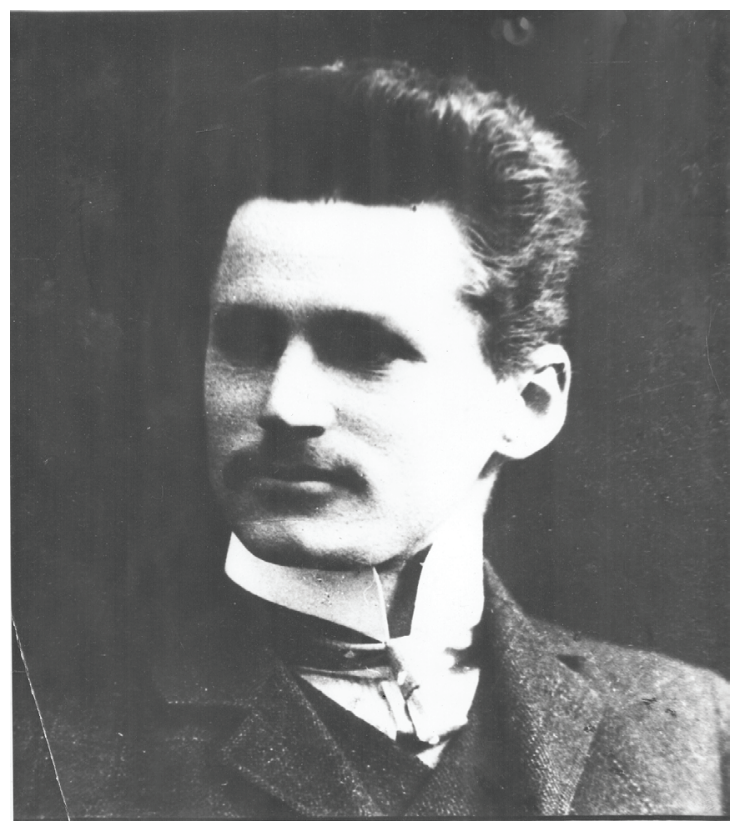

Фото 2. П.В. Виттенбург - студент Тюбингенского университета. 1909 г. встречал со стороны строителей Владивостокской крепости: начальника военных инженеров генерал-майора Алексея Петровича Шошина, военных инженеров Вячеслава Владиславовича Буйко, Евгения Павловича Проценко, Михаила Петровича Субботина, Николая Михайловича Гридина и других. Они не только проявляли большую заинтересованность в работе ученого, но и оказывали ему всяческую поддержку.

Виттенбург обязался по результатам экспедиции подготовить к изданию геологическую карту обследованного района. В конце 1912 г. Н.М. Соловьев и его заместитель С.А. Трон провели сбор пожертвований на издание карты, собрав 2450 руб., а в конце 1916 г. в "Записках Общества изучения Амурского края" напечатали масштабную работу геолога, которая подвела итог его исследованиям во Владивостоке [2].

Павел Владимирович писал в посвящении Н.М. Соловьеву: "Более десяти лет тому назад у Вас созрела мысль подвергнуть всестороннему изучению в естественно-историческом отношении полуостров Муравьева-Амурского и архипелаг Императрицы Евгении. Неоднократно Вы входили в распорядительный комитет Общества изучения Амурского края с соответствующим проектом. Не ограничиваясь одним искренним желанием познать природу и строение ближайших окрестностей Владивостока и центральной части полуострова, в литературе почти не освещенной, Вы старались при первой возможности перейти к делу. [...] При всех моих работах и начинаниях я встречал с Вашей стороны, глубокоуважаемый Николай Матвеевич, самое живое и искреннее внимание и самый исключительный интерес к геологии края, и, естественно, что только Вам могу посвятить свои строки, принося настоящим свою душевную благодарность за оказанное мне доверие и предоставленную возможность изучить, хотя бы весьма приближенно, исторические документы той части Восточной Сибири, которая живо меня интересует с точки зрения изменения материков и морей в смене времен" [2, c. vii-ix].

Известен интересный факт. Соловьеву так нравился энергичный и целеустремленный Виттенбург, что он хотел отдать замуж за него свою дочь Маргариту. Он был обескуражен, когда узнал, что тот женился вскоре после окончания университета, взяв в жены студентку Женского медицинского института в Санкт-Петербурге Зинаиду Ивановну Разумихину. А Маргарита Соловьева позднее вышла замуж за В.К. Арсеньева. 


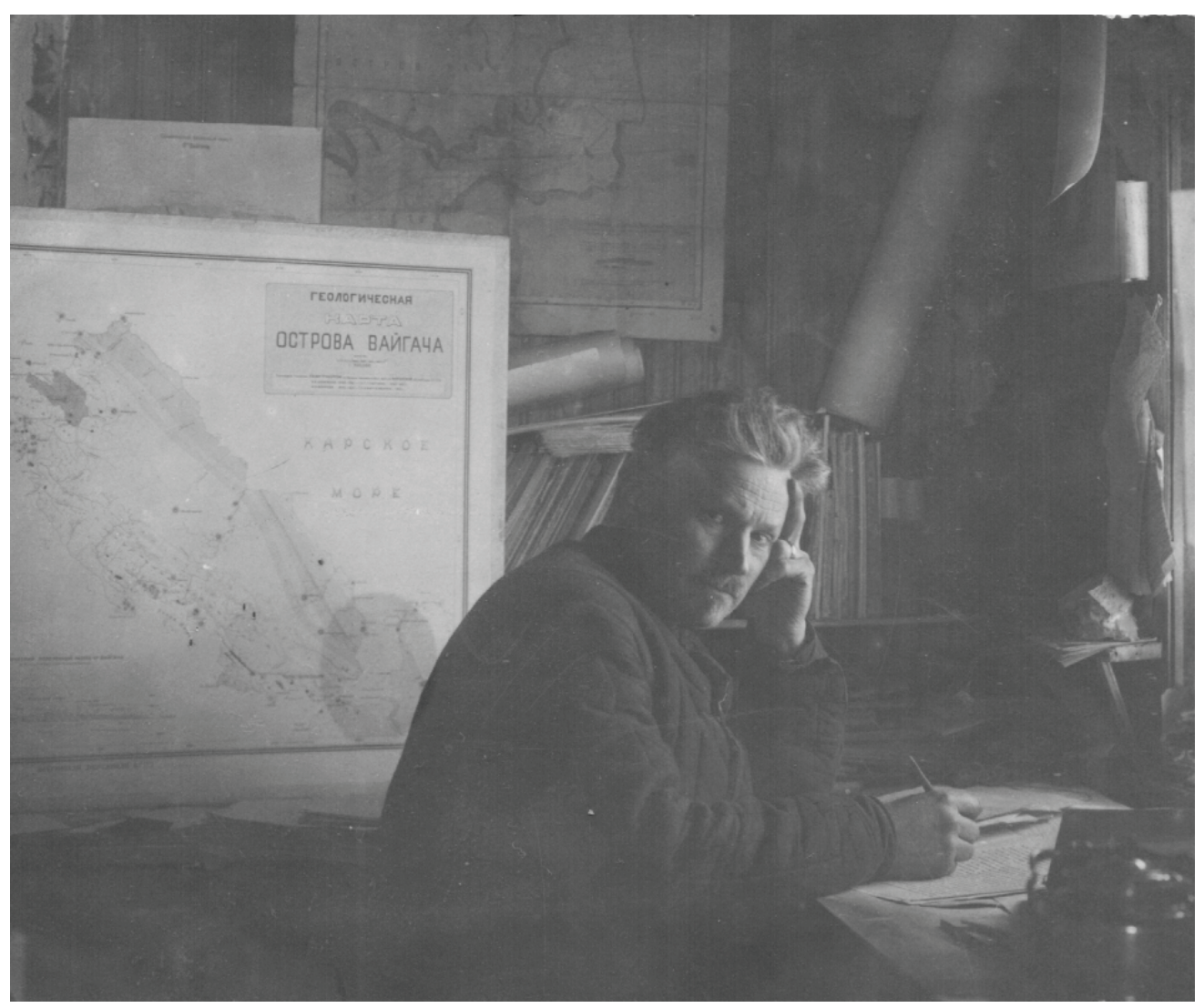

Фото З. П.В. Виттенбург - Вайгачская экспедиция ОГПУ. Лагерь, 1932 г.

За книгу "Геологическое описание полуострова Муравьев-Амурский и архипелага императрицы Евгении" Харьковский университет удостоил П.В. Виттенбурга степени магистра минералогии и геологии (1916), ему также присудили Малую премию им. Н.М. Ахматова по физико-математическому отделению ИАН (8 ноября 1917). Общество изучения Амурского края наградило его премией имени Ф.Ф. Буссе за исследования полуострова Муравьёва-Амурского в геологическом отношении. Особую ценность в работе Виттенбурга представляет исторический и картографический очерк, в котором опубликованы уникальные карты, который геолог выявил при помощи известного китаеведа Василия Михайловича Алексеева [2, с. 1-61].

В мае 1917 г. Виттенбург вновь приехал во Владивосток: Академия наук командировала его на летние месяцы в Южно-Уссурийский край для продолжения геологических исследований береговой полосы залива Петра Великого. В это время вернулся с фронта бывший препаратор музея ОИАК Анатолий Григорьевич Кузнецов, вместе с которым геолог совершил месячную поездку, собирая геологическую коллекцию. Чуть позже он продолжил эту работу совместно с японским профессором Котора Дзимбо (1867-1924) из Токио. В этот период Виттенбург уделил особое внимание островам, детально изучив Путятин, Аскольд и ряд других островов залива Петра Великого. В поле его зрения попали и угольные месторождения, в частности, Монгугайское на западном побережье Амурского залива, близ пос. Барабаш. Н.П. Крылов организовал в ОИАК выставку петрографической коллекции по сборам Виттенбурга: она разместилась в восьми витринах в том порядке, в которой отмечена в книге геолога "Научные результаты геологической әкспедиции 1912 г.".

Непросто складывалась жизнь П.В. Виттенбурга в советское время (gбото 4). Впервые его арестовали как заложника в связи с Кронштадтским восстанием [7, с. 39-40], но это не повлияло на его научную карьеру. Она 


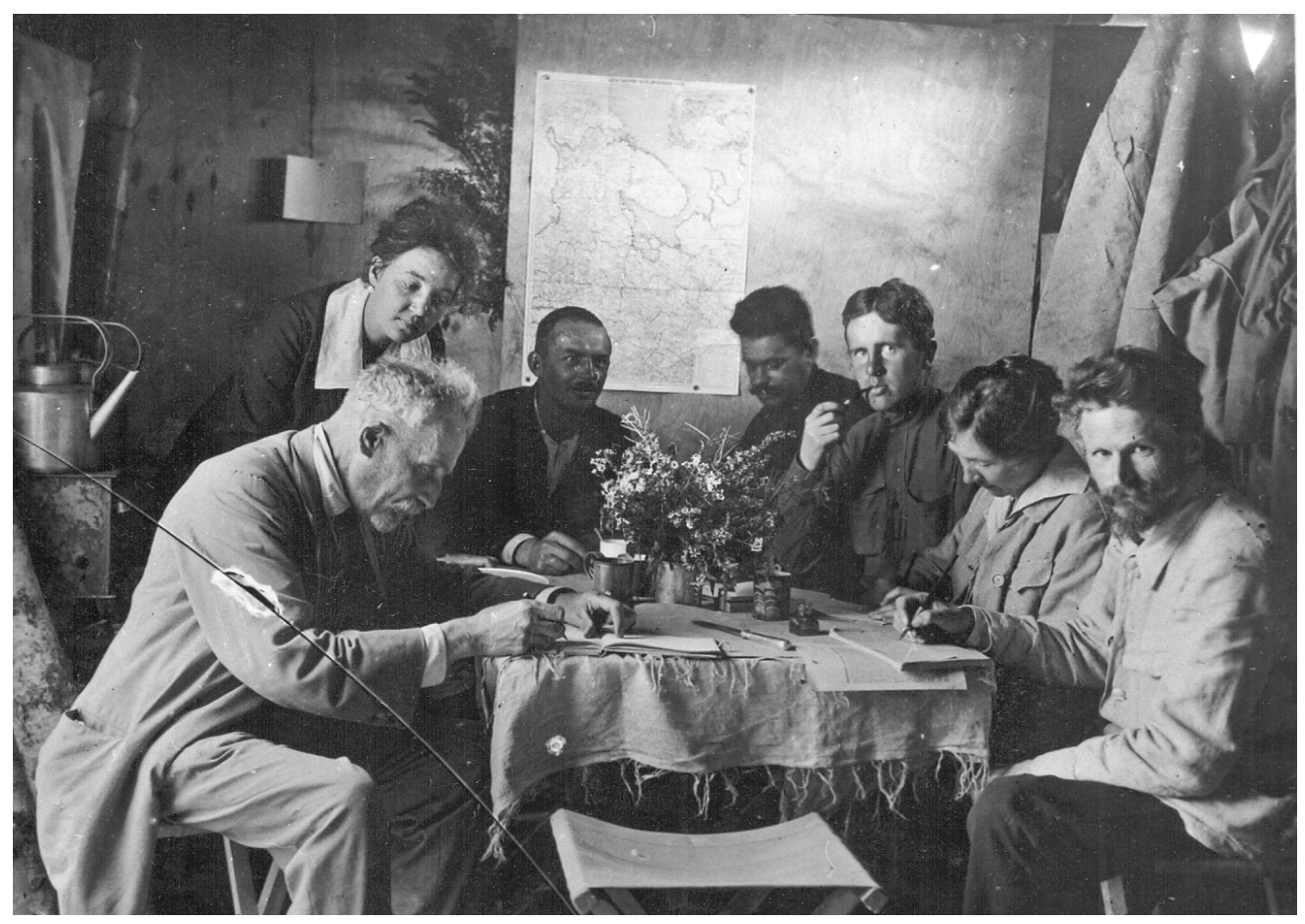

Фото 4. П.В. Виттенбург (справа) и художник Альберт Николаевич Бенуа (слева) (1852 - 1936, Париж). Вагон - теплушка (1920).

успешно продолжилась после освобождения геолога. Виттенбург был старшим гидрологом-заведующим отделом морфологии морских берегов Российского гидрологического института при Российской АН (1919-30) и ответственным секретарем Якутской комиссии РАН (1925-30). В это время он прислал две книги В.К. Арсеньеву [3; 4].

1930-е гг. многое изменили в судьбе большинства исследователей Дальнего Востока. 6 марта 1930 г. арестовали бывшего председателя ОИАК H.M. Соловьева, а 15 апреля 1930 г. пришли за Виттенбургом. Его арестовали по "Академическому делу" и 11 февраля 1931 г. приговорили к расстрелу, заменив затем приговор на десять лет исправительно-трудовых лагерей. В заключении геолог сначала работал на лесоповале в районе строительства Беломорско-Балтийского канала, но осенью 1931 г. его отправили на остров Вайгач, где он работал по специальности: был рудничным геологом, а затем начальником геологической части и старшим геологом Вайгачской экспедиции ОГПУ. В 1932 г. (фбото 3) Виттенбург руководил геологическими работами изыскания на Югорском полуострове, в ходе которых было открыто месторождение ценного минерала фрююрита, самое крупное в стране на то время.

2 июля 1935 г. его освободили, но клеймо врага народа Павел Владимирович носил 22 года, пока его не реабилитировали 13 декабря 1957 г. В 19361941 гг. он проводил геологические исследования на Таймыре и в Воркуте. В годы Великой Отечественной войны преподавал в Карело-Финском университете, затем заведовал кафедрой физической географии Арктики в Ленинградском высшем арктическом морском училище (1946-1950) (o6ото. 1). В последние годы жизни, начиная с 1954 г., доктор геолого-минералогических наук П.В. Виттенбург работал во Всесоюзном геологическом институте.

Ныне редко какая краеведческая книга в Приморье обходится без упоминания имени П.В. Виттенбурга, чьи заслуги отмечены не только в геологии, но и в топонимии Владивостока. На своей геологической карте он оставил имена коллег и тех, кто способствовал его экспедициям в окрестностях Владивостока. Эти названия сохраняются и поныне. А одна из гор на полуострове Муравьева-Амурского названа именем Виттенбурга. 


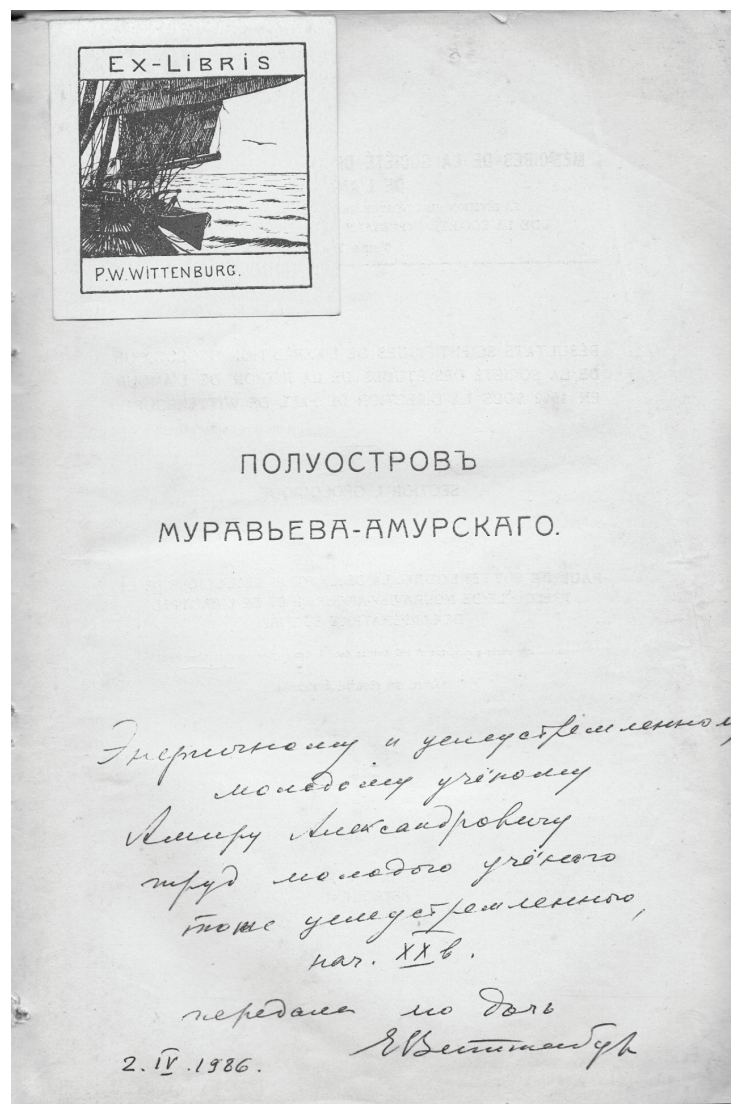

Павел Владимирович Виттенбург скончался 29 января 1968 г. в Зеленогорске под Санкт-Петербургом, там же похоронен, могила сохраняется - огромный дикий валун.

Фото 5. Титульный лист монографии П.В. Виттенбурга с дарственной надписью Е.П. Виттенбург.

\section{Литература}

1. Виттенбург Е.П. Павел Виттенбург: Геолог, полярник, узник ГУЛАГа: (воспоминания дочери). Санкт-Петербург: Нестор-история СПб РАН, 2003. 431 с.: ил.

2. Виттенбург П.В. Геология полуострова Муравьев-Амурский: Научные результаты геологической экспедиции Общества изучения Амурского края в 1912 г. под начальством П.В. Виттенбурга. Ч.1. Геологическая. Геологическое описание полуострова Муравьева-Амурского и архипелага императрицы Евгении. Петроград: Тип. М. Стасюлевича. 1916. 480. XXX с.: ил., табл.

3. Виттенбург П.В. Якутская экспедищия Академии наук. Ленинград.: Изд-во АН СССР, 1925. 157 с., 1 л. карта. (АН СССР. Материалы по изучению Якутской АССР. Вып.1).

4. Виттенбург П., Рабо Ш. Полярные страны 1914 - 1924. Ленинград: Изд-во отд. морского ведомства, 1924. 182 с., ил, карта; табл.

5. Отчет за 1908 год Общества изучения Амурского края (Филиальное отделение Приамурского отдела Императорского Русского географического общества. Владивосток: Тип. Н.П. Матвеева, 1910. 12 с.

6. Отчет ОИАК за 1912 год. Владивосток: Тип. В.К. Иогансона, 1916. 14 с.

7. Репрессированные геологи. Санкт-Петербург: ВСЕГЕИ, 1995. 169 с.

8. Wittenburg Paul. Neue Beitrage zur Geologie und Palaontologie der Werfener Schichten Sudrirols, mit Berucksichtigung der Schichten von Wladivostok. Stuttgart, 1908. 200 S. 6789 : il. (Separat-Abdruck aus dem Centralblatt fur Mineralogie, Geologie und Palaontologie Jahrg; 1908, bd. 3). 


\section{Транслитерация по ГОСТ 7.79-2000 Система Б}

1. Vittenburg E.P. Pavel Vittenburg: Geolog, polyarnik, uznik GULAGa: (vospominaniya docheri). Sankt-Peterburg: Nestor-istoriya SPb RAN, 2003. 431 s.: il.

2. Vittenburg P.V. Geologiya poluostrova Murav'ev-Amurskij: Nauchnye rezul'taty geologicheskoj ehkspeditsii Obshhestva izucheniya Amurskogo kraya v 1912 g. pod nachal'stvom P.V. Vittenburga. CH.1. Geologicheskaya. Geologicheskoe opisanie poluostrova Murav'eva-Amurskogo i arkhipelaga imperatritsy Evgenii. Petrograd: Tip. M. Stasyulevicha. 1916. 480. XXX s.: il., tabl.

3. Vittenburg P.V. YAkutskaya ehkspeditsiya Akademii nauk. Leningrad.: Izd-vo AN SSSR, 1925. 157 s., 1 l. karta. (AN SSSR. Materialy po izucheniyu YAkutskoj ASSR. Vyp.1).

4. Vittenburg P., Rabo SH. Polyarnye strany 1914 - 1924. Leningrad: Izd-vo otd. morskogo vedomstva, 1924. 182 s., il, karta; tabl.

5. Otchet za 1908 god Obshhestva izucheniya Amurskogo kraya (Filial'noe otdelenie Priamurskogo otdela Imperatorskogo Russkogo geograficheskogo obshhestva. Vladivostok: Tip. N.P. Matveeva, 1910. 12 s.

6. Otchet OIAK za 1912 god. Vladivostok: Tip. V.K. Iogansona, 1916. 14 s.

7. Repressirovannye geologi. Sankt-Peterburg: VSEGEI, 1995. 169 s.

8. Wittenburg Paul. Neue Beitrage zur Geologie und Palaontologie der Werfener Schichten Sudrirols, mit Berucksichtigung der Schichten von Wladivostok. Stuttgart, 1908. 200 S. 6789 : il. (Separat-Abdruck aus dem Centralblatt fur Mineralogie, Geologie und Palaontologie Jahrg; 1908, bd. 3).

Хисамутдинов А. А., Хисамутдинова Н. В. Геолог Владивостокской крепости Павел Виттенбург.

Статья посвящена известному российскому геологу, географру - почетному полярнику профессору Павлу Владимировичу Виттенбургу, который провел геологические исследования на полуострове Муравьева-Амурского (Японское море) для нужд Владивостокской крепости. Находки стали основой масштабной монографоии "Научные результаты Геологической экспедиции Общества изучения Амурского края в 1912 году под начальством П.В. Виттенбурга" (Петроград, 1916). Несмотря на научные достижения, Виттенбург был дважды репрессирован. В дальнейшем проводил различные исследования в Арктике и занимался преподавательской деятельностью. Для статьи использованы материалы из архива Е.П. Виттенбург.

Ключевые слова: П.В. Виттенбург, Н.М. Соловьев, история геологии, полуостров Муравьева-Амурского, топонимика Владивостока

Khisamutdinov A. A., Khisamutdinova N. V. Geologist of the Vladivostok Fortress Pavel Wittenburg.

The article is devoted to the famous Russian geologist, geographer, honorary polar explorer and professor Pavel Vladimirovich Wittenburg, who conducted geological research on the Muravyov-Amursky peninsula (Sea of Japan) for the needs of the Vladivostok fortress. The finds became the basis for a large-scale monograph "Scientific Results of the Geological Expedition of the Society for the Study of the Amur Region in 1912 under the leadership of P.V. Wittenburg (Petrograd, 1916). Wittenburg was purged twice. Later, he conducted various studies in the Arctic and was engaged in teaching activities. The article based on the collection of E.P. Wittenburg.

Key words: P.V. Wittenburg, N.M. Soloviev, history of geology, Muravyov Amursky peninsula, Vladivostok toponymy

Для цитирования: Хисамутдинов А. А., Хисамутдинова Н. В. Геолог Владивостокской крепости Павел Виттенбург // Ойкумена. Регионоведческие исследования. 2021. № 2. C. 39-45. DOI: 10.24866/1998-6785/2021-2/39-45

For citation: Khisamutdinov A. A., Khisamutdinova N. V. Geologist of the Vladivostok Fortress Pavel Wittenburg // Ojkumena. Regional researches. 2021. № 2. P. 39-45. DOI: 10.24866/1998$6785 / 2021-2 / 39-45$ 